\title{
Cetacean records along a coastal-offshore gradient in the Vitória- Trindade Chain, western South Atlantic Ocean
}

\author{
Wedekin, LL. ${ }^{\text {** }}$, Rossi-Santos, MR. a , Baracho, C. a, \\ Cypriano-Souza, AL. ${ }^{\mathrm{a}, \mathrm{b}}$ and Simões-Lopes, $P C^{\mathrm{c}}$ \\ anstituto Baleia Jubarte, Rua Barão do Rio Branco, 125, CEP 45900-000, Caravelas, BA, Brazil \\ bLaboratório de Biologia Genômica e Molecular, Faculdade de Biociências, Pontifícia Universidade Católica do Rio \\ Grande do Sul - PUCRS, Avenida Ipiranga, 6681, CEP 90619-900, Porto Alegre, RS, Brazil \\ 'Laboratório de Mamíferos Aquáticos - LAMAQ, Departamento de Ecologia e Zoologia, Universidade Federal de Santa \\ Catarina - UFSC, Campus Universitário, CP 5102, Trindade, CEP 88040-970, Florianópolis, SC, Brazil \\ *e-mail: lwedekin@yahoo.com.br
}

Received: November 2, 2012 - Accepted: December 27, 2012 - Distributed: February 28, 2014

(With 2 figures)

\begin{abstract}
Oceanic waters are difficult to assess, and there are many gaps in knowledge regarding cetacean occurrence. To fill some of these gaps, this article provides important cetacean records obtained in the winter of 2010 during a dedicated expedition to collect visual and acoustic information in the Vitória-Trindade seamounts. We observed 19 groups of cetaceans along a 1300-km search trajectory, with six species being identified: the humpback whale (Megaptera novaeangliae, $\mathrm{N}=9$ groups), the fin whale (Balaenoptera physalus, $\mathrm{N}=1$ ), the Antarctic minke whale (Balaenoptera bonaerensis, $\mathrm{N}=1$ ), the rough-toothed dolphin (Steno bredanensis, $\mathrm{N}=1$ ), the bottlenose dolphin (Tursiops truncatus, $\mathrm{N}=2$ ), and the killer whale (Orcinus orca, $\mathrm{N}=1)$. Most humpback whale groups $(\mathrm{N}=7 ; 78 \%)$ were observed in the Vitória-Trindade seamounts, especially the mounts close to the Abrolhos Bank. Only one lone humpback whale was observed near Trindade Island after a search effort encompassing more than $520 \mathrm{~km}$. From a total of 28 acoustic stations, humpback whale songs were only detected near the seamounts close to the Abrolhos Bank, where most groups of this species were visually detected (including a competitive group and groups with calves). The presence of humpback whales at the Trindade Island and surroundings is most likely occasional, with few sightings and low density. Finally, we observed a significant number of humpback whales along the seamounts close to the Abrolhos Bank, which may function as a breeding habitat for this species. We also added important records regarding the occurrence of cetaceans in these mounts and in the Western South Atlantic, including the endangered fin whale.
\end{abstract}

Keywords: Megaptera novaeangliae, Balaenoptera physalus, Balaenoptera bonaerensis, Orcinus orca, Steno bredanensis, Tursiops truncatus, seamounts, Brazil.

\section{Registros de cetáceos ao longo de um gradiente costeiro-pelágico na Cadeia Vitória-Trindade, Oceano Atlântico Sul ocidental}

\section{Resumo}

Águas oceânicas e afastadas da costa são ambientes de difícil acesso e muitas lacunas de conhecimento sobre a ocorrência de cetáceos ainda existem. O presente trabalho fornece importantes registros realizados durante uma expedição dedicada a procurar cetáceos visualmente e acusticamente na Cadeia Vitória-Trindade no inverno de 2010. Foram observados 19 grupos de cetáceos ao longo de $1300 \mathrm{~km}$ de esforço, sendo identificadas seis espécies: a baleia-jubarte (Megaptera novaeangliae, $\mathrm{N}=9$ grupos), a baleia-fin (Balaenoptera physalus, $\mathrm{N}=1$ ), um grupo misto de baleia-minke-Antártica (Balaenoptera bonaerensis) e golfinhos-de-dentes-rugosos (Steno bredanensis, $\mathrm{N}=1$ ), o golfinho-nariz-de-garrafa (Tursiops truncatus, $\mathrm{N}=2$ ) e a orca (Orcinus orca, $\mathrm{N}=1)$ ). A maioria dos grupos da baleia-jubarte $(\mathrm{n}=7 ; 78 \%)$ foram observados nos montes marinhos da Cadeia Vitória-Trindade, especialmente os montes próximos do Banco dos Abrolhos. Somente uma baleia-jubarte solitária foi observada próxima da Ilha Trindade, apesar de mais de $520 \mathrm{~km}$ percorridos em esforço na região. De um total de 28 estações acústicas, cantos da baleia-jubarte foram detectados somente nos montes próximos ao Banco dos Abrolhos, onde a maioria dos grupos desta espécie foi observada visualmente (incluindo grupos competitivos e fêmeas com filhotes). A presença da baleia-jubarte nos arredores da Ilha de Trindade é provavelmente ocasional, com poucos indivíduos e baixa densidade. Finalmente, um número expressivo de grupos de baleia-jubarte foi observado sobre os montes próximos do Banco dos Abrolhos, que podem funcionar como habitats reprodutivos da espécie. Adicionaram-se ainda importantes registros de cetáceos na Cadeia Vitória-Trindade e no Oceano Atlântico Sul ocidental, incluindo a baleia-fin, uma espécie ameaçada de extinção.

Palavras-chave: Megaptera novaeangliae, Balaenoptera physalus, Balaenoptera bonaerensis, Orcinus orca, Steno bredanensis, Tursiops truncatus, cordilheira submarina, Brasil. 


\section{Introduction}

The majority of cetacean species ( $\sim 53 \%)$ are classified as "Data Deficient" by the International Union for Conservation of Nature (IUCN, 2012). This lack of knowledge is partly due to the inherent difficulties of studying marine mammals, especially those inhabiting offshore waters. In fact, a closer look at the IUCN red list data base indicates that more than half of those listed as "Data Deficient" live primarily in pelagic environments and may never approach the coast (Jefferson et al., 2008; IUCN, 2012). In Brazil, search efforts for cetaceans in pelagic waters are rare (e.g., Andriolo et al., 2010b).

The humpback whale, Megaptera novaeangliae (Borowski, 1781), is a seasonal migrant, moving between summer feeding grounds and wintering breeding habitats (Kellogg, 1929). One of the humpback whale's seven breeding areas in the Southern Hemisphere is located in the coastal waters of Brazil (IWC, 1998). Breeding stock A (IWC, 1998) refers to the population wintering along the eastern and northeastern coast of Brazil, from $6^{\circ}$ to $24^{\circ} \mathrm{S}$ (Andriolo et al., 2010a). The large and shallow Abrolhos Bank is the area of highest density within the known distribution of humpback whales in Brazil (Andriolo et al., 2010a), but additional records have been made near oceanic islands, such as the Archipelago of Fernando de Noronha (Lodi, 1994) and the Trindade Island (Townsend, 1935; Siciliano, 1997).

Studies of population structure using DNA and within breeding ground movements in the coast of Brazil suggest there is a limited population substructure within the Brazilian humpback whale population (Cypriano-Souza et al., 2010; Wedekin et al., 2010). These studies, however, only considered genetic samples and photo-identification data from whales sampled near the coast of Brazil. Therefore, the stock identity of whales sighted near oceanic islands is still unclear. In addition, the density of whales near these sites is unknown, especially compared with the relatively large abundance found closer to the South American continent. Considering the current scarcity of research efforts, more studies have been recommended to further investigate the stock identity of humpback whales seen near the oceanic islands off Brazil (IWC, 2006).

The objectives of the present study were the following: (a) to assess the distribution of cetaceans in the VitóriaTrindade seamounts and adjacent oceanic waters; (b) to verify the presence of humpback whales in the seamounts based on visual and acoustic detection; and (c) to provide new information concerning the breeding stock identity of the humpback whales that breed in Brazilian waters. These data were obtained during a dedicated expedition to collect visual and acoustic information regarding the presence of cetaceans in the Vitória-Trindade seamounts in the winter of 2010 .

\section{Material and Methods}

The Vitória-Trindade Chain is a range of seamounts that stretches linearly from west to east at $\sim 21^{\circ} \mathrm{S}$, beginning in the southeastern Abrolhos Bank $\left(\sim 38^{\circ} \mathrm{W}\right)$ and reaching its easternmost point at the Martin Vaz Archipelago and Trindade Island $\left(\sim 29^{\circ} \mathrm{W}\right)$ (Figure 1$)$. This region is under the influence of the warm Brazil Current that runs from north to south bordering the continent. The Trindade Island is located more than $1100 \mathrm{~km}$ from mainland Brazil. A total of eight disconnected seamounts emerge from the

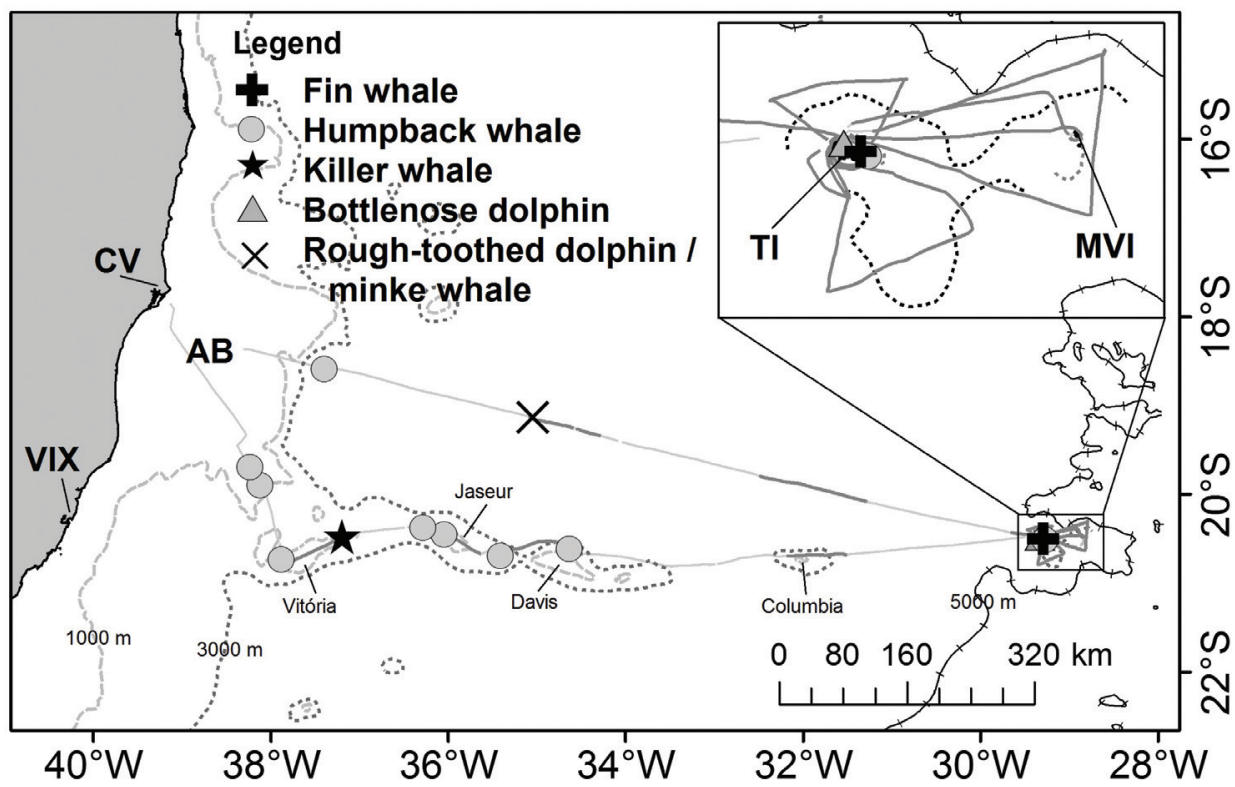

Figure 1. Cetacean sightings during the expedition to the Vitória-Trindade seamounts in the winter of 2010. The light gray line shows the route followed by the boat, with the route on-effort marked with dark gray. Locations: Caravelas (CV), Vitória (VIX), Abrolhos Bank (AB), Trindade Island (TI), and Martin Vaz Island (MVI). 
sea floor at depths of approximately $2000 \mathrm{~m}$ or more and reach depths of 50 to $100 \mathrm{~m}$. Only two seamounts emerge above the sea, and their peaks correspond to Trindade and Martin Vaz Islands. These islands have narrow continental shelves and a steep slope. The closest point to Trindade Island on the continent of Brazil is the city of Caravelas $(1080 \mathrm{~km})$, from where the expeditions departed and arrived.

The expedition was held at the peak of the humpback whale breeding season in Brazil (see Martins et al., 2001), from August 19 to September 6, 2010, with 15 days of sampling. The 18-m catamaran Voyager, equipped with two diesel-powered engines, was used as the observation platform. Three observers, one in the bow and two on each side of the vessel at the upper deck ( $5 \mathrm{~m}$ above the sea), used $7 \times 50$ binoculars to search for cetaceans in good visibility conditions (daylight, Beaufort scale $<4$ ). Visibility and oceanographic conditions (e.g., wind speed, sea state) were recorded at 2-h intervals or when conditions changed. The vessel route was recorded with the GPS 'track' function (positions recorded at 5-min intervals). All geographic information (routes, sightings, bathymetry, continental coastline and islands) were integrated into a Geographic Information System (GIS) (ESRI, ArcGIS 10).

In addition to visual surveys, acoustic stations were sampled whenever possible to record male humpback whale songs (see Payne and McVay (1971), for a description of this behavior). Recordings were made using a hydrophone and pre-amplifiers (Cetacean Research, model C304) and a digital recorder (Fostex, model FR-2), with a frequency response of up to $192 \mathrm{kHz}$. We were able to aurally identify whether more than one singer was present when different song themes overlapped, generally with different signal powers differentiating between singers.

When a group was sighted, the vessel left the trackline and closed in to record species identification (Jefferson et al., 2008), group size and composition, geographical position (GPS), and behavior. Individual photo-identification data were also documented for humpback whales using the black and white pigmentation of the ventral surface of their flukes (Katona and Whitehead, 1981). Skin samples were also collected for humpback whales using a crossbow (Barnett, model Wildcat XL, $15 \mathrm{lb}$ ) and arrows with $15 \times 8-\mathrm{mm}$ cylindrical stain-less steel tips (Cypriano-Souza et al., 2010). Biopsy samples were preserved in $70 \%$ ethanol. After 30 to $60 \mathrm{~min}$ of approach, the group was left behind and the boat resumed the survey trackline to search for other groups.

\section{Results}

\subsection{Field effort and cetacean records}

A total of $1300 \mathrm{~km}$ was surveyed, and 19 cetacean groups were detected. Of these groups, 26\% $(\mathrm{N}=5)$ could not be identified to the species level. The remaining sightings corresponded to six cetacean species (Table 1, Figure 1): the humpback whale - Megaptera novaeangliae ( $\mathrm{N}=9$ groups), the Antarctic minke whale - Balaenoptera bonaerensis Burmeister, $1867(\mathrm{~N}=1)$, the fin whale Balaenoptera physalus (Linnaeus, 1758) $(\mathrm{N}=1)$, the bottlenose dolphin - Tursiops truncatus (Montagu, 1821) $(\mathrm{N}=2)$, the rough-toothed dolphin - Steno bredanensis (G. Cuvier in Lesson, 1828) ( $\mathrm{N}=1)$, and the killer whale - Orcinus orca (Linnaeus, 1758) $(\mathrm{N}=1)$.

\subsection{Humpback whales}

Nine groups of humpback whales were observed, with the group size varying from 1 to 6 whales (average $=3$; $\mathrm{SD}=1.6)$. Females with newborn calves corresponded to $56 \%(\mathrm{~N}=5)$ of the sightings. The largest was a competitive group of six whales (see Tyack and Whitehead (1983), for a description of this behavior). The depths of the humpback whale sightings varied from 56 to $3378 \mathrm{~m}$, with only two groups being observed in waters deeper than $150 \mathrm{~m}$ (Figure 1). Most humpback sightings $(\mathrm{N}=7 ; 77.8 \%)$

Table 1. Groups of identified cetaceans observed during the expedition to the Vitória-Trindade seamounts in the winter of 2010.

\begin{tabular}{ccccc}
\hline Date & Species & Geographical position & Adult (calf) & Depth (m) \\
\hline August 20 & $\begin{array}{c}\text { Megaptera novaeangliae } \\
\text { Steno bredanensis }+\end{array}$ & $18.59^{\circ} \mathrm{S}-39.40^{\circ} \mathrm{W}$ & $2(1)$ & 3378 \\
August 21 & $\begin{array}{c}\text { Balaenoptera bonaerensis } \\
\text { Tursiops truncatus }\end{array}$ & $19.14^{\circ} \mathrm{S}-35.05^{\circ} \mathrm{W}$ & $29(1)+2$ & 4123 \\
August 30 & T. truncatus & $20.49^{\circ} \mathrm{S}-29.32^{\circ} \mathrm{W}$ & 4 & 20 \\
August 30 & M. novaeangliae & $20.59^{\circ} \mathrm{S}-29.32^{\circ} \mathrm{W}$ & $9(1)$ & 30 \\
August 31 & Balaenoptera physalus & $20.51^{\circ} \mathrm{W}-29.29^{\circ} \mathrm{W}$ & 1 & 150 \\
August 31 & M. novaeangliae & $20.62^{\circ} \mathrm{S}-34.64^{\circ} \mathrm{W}$ & 2 & 65 \\
September 02 & M. novaeangliae & $20.70^{\circ} \mathrm{S}-35.42^{\circ} \mathrm{W}$ & $2(1)$ & 68 \\
September 02 & M. novaeangliae & $20.45^{\circ} \mathrm{S}-36.05^{\circ} \mathrm{W}$ & $1(1)$ & 59 \\
September 03 & M. novaeangliae & $20.38^{\circ} \mathrm{S}-36.29^{\circ} \mathrm{W}$ & $2(1)$ & 56 \\
September 03 & Orcinus orca & $20.49^{\circ} \mathrm{S}-37.19^{\circ} \mathrm{W}$ & 2 & 695 \\
September 04 & M. novaeangliae & $20.73^{\circ} \mathrm{S}-37.88^{\circ} \mathrm{W}$ & 6 & 69 \\
September 04 & M. novaeangliae & $19.90^{\circ} \mathrm{S}-38.13^{\circ} \mathrm{W}$ & $1(1)$ & 65 \\
September 05 & M. novaeangliae & $19.69^{\circ} \mathrm{S}-38.24^{\circ} \mathrm{W}$ & 5 & 69 \\
September 05 & & & \\
\hline
\end{tabular}


were observed along the Vitória-Trindade seamounts, especially the mounts close to the Abrolhos Bank. Only one humpback whale was seen near Trindade, despite a search effort of 6 days and $520 \mathrm{~km}$.

Humpback whale songs were only heard near seamounts close to the Abrolhos Bank, where most groups of this species (including a competitive group) were visually detected (Figure 2). One singer was detected at $14 \%(\mathrm{~N}=4)$ of the 28 acoustic stations, and at least two singers were recorded at $7 \%(\mathrm{~N}=2)$. Songs were not heard during the trip over oceanic waters from Caravelas to Trindade Island or in the surroundings of the Martin Vaz and Trindade Islands, where few groups were visually detected.

Nine humpback whales were photo-identified and were compared with a catalogue of 3785 whales, mainly from the Abrolhos Bank (1989-2010, Wedekin et al. (2010)), and to another catalogue of 968 individuals from the northern coast of Bahia (2001-2010, Baracho-Neto et al. (2012)). No matches were observed between the catalogues.

A total of four skin samples were genotyped using ten microsatellite loci for individual identification and were compared with 613 samples from the Abrolhos Bank (19992009, Cypriano-Souza et al. (2010)). Two samples were replicates of the same individual (a biopsy and a sloughed skin sample). No matches were found between the three left-over samples and those from the Abrolhos Bank.

\subsection{Other cetacean records}

Below, we provide descriptions of the encounters with the five remaining species of cetaceans observed during the expedition:

A mixed group of two Antarctic minke whales and thirty rough-toothed dolphins (with a single calf) was encountered in waters $4123 \mathrm{~m}$ deep and $460 \mathrm{~km}$ from the coast. The whales were observed to constantly show their white ventral belly just above or below the water, swimming laterally or belly-up. The animals were also observed trying to climb one another with their bellies and then roll their bodies, which strongly suggested mating activity. The whales were frequently changing direction in the same area (milling) and many times stayed close to the research vessel. Both were adults (approx. 7-8 m), but one whale was approximately one meter larger than the other, and the smaller individual was constantly chasing the larger whale. After approximately $20 \mathrm{~min}$ of following the mixed group, four researchers dove with snorkels to obtain underwater images of the group. The dolphins approached and swam around the divers for approximately another $20 \mathrm{~min}$. The large group of dolphins was divided into sub-groups of two to six individuals that swam close to each other.

Two groups of bottlenose dolphins were observed near the Trindade Island (less than $2 \mathrm{~km}$ from the shore) at depths of 20 and $30 \mathrm{~m}$. The groups were sighted in the morning (8:30 AM, four dolphins) and in the afternoon (4:10 PM, ten dolphins with one calf) on the same day and in the same general area (northeastern end of the island).

Two adult fin whales were observed near the Trindade Island, less than $1 \mathrm{~km}$ from the shore at a depth of $65 \mathrm{~m}$. The whales were swimming fast and were milling, always close to each other, and on one occasion it was possible to observe one whale swimming laterally.

One group of two killer whales was observed at a depth of $62 \mathrm{~m}$ near the Bank of Vitória, southeastern Abrolhos Bank. One adult male (judged by its tall and

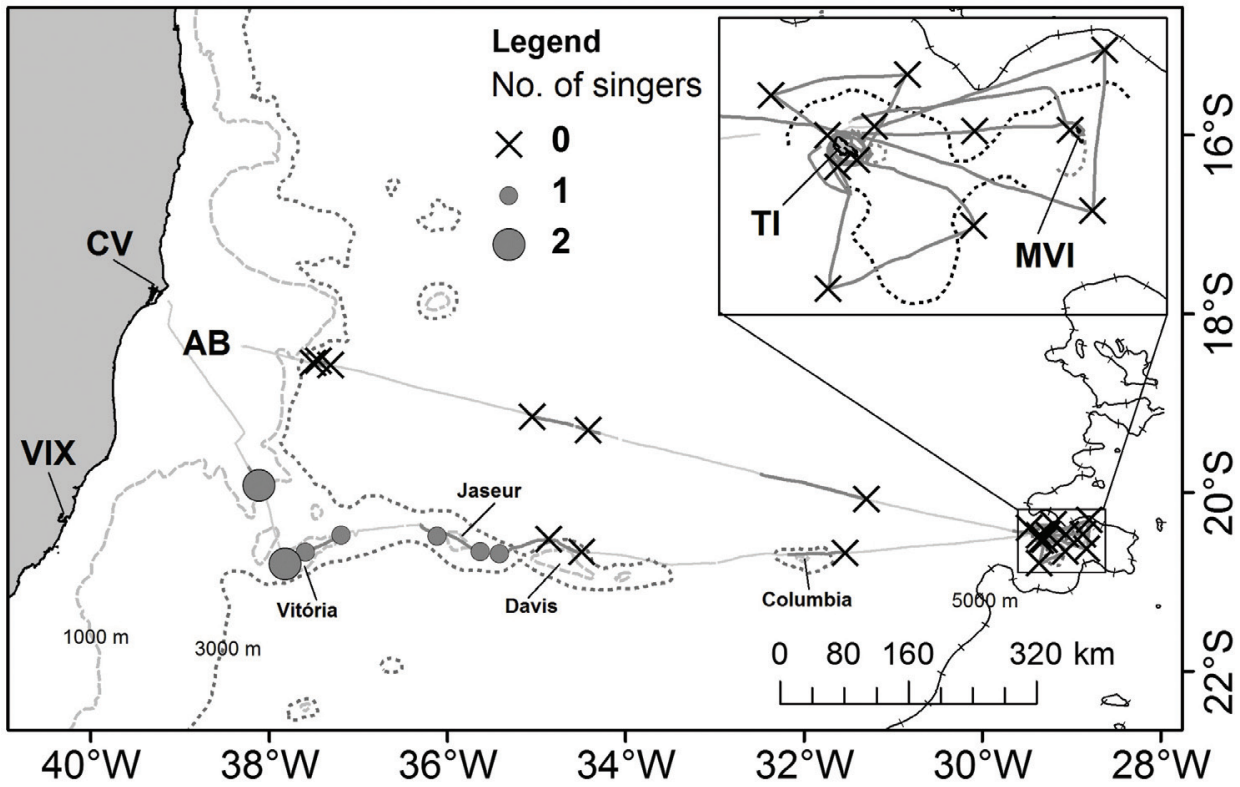

Figure 2. Acoustic stations $(n=28)$ of the expedition to the Vitória-Trindade seamounts in the winter of 2010. The light gray line shows the route followed by the boat, with the route on-effort marked with dark gray. Locations: Caravelas (CV), Vitória (VIX), Abrolhos Bank (AB), Trindade Island (TI), and Martin Vaz Island (MVI). 
straight dorsal fin) and another smaller juvenile or female individual (falcate dorsal fin) were sighted.

\section{Discussion}

\subsection{Humpback whales in oceanic islands}

With the exception of the São Pedro and São Paulo Archipelago $\left(0^{\circ} 55^{\prime} \mathrm{N}-29^{\circ} 21^{\prime} \mathrm{W}\right)$ and the Archipelago of Martin Vaz (20²9' S-28 52' W), humpback whales have been observed in the main oceanic islands off Brazil, including the Fernando de Noronha Archipelago ( $3^{\circ} 51^{\circ}$ S-32 $25^{\prime}$ W; Lodi (1994)), the Rocas Atoll (3 $51^{\prime}$ S-33 ${ }^{\circ}$ 49' W; Silva and Godoy (2010)), and Trindade Island (2031' S-29 19' W; Siciliano (1997)). Most observations have been made from land and/or have been opportunistic. The haphazard nature of these data limit any inference about abundance, seasonality, or stock identity of the species. Dedicated boat expeditions have the advantage that the spatial coverage is greater, as they are not limited to the areas near the coasts of the islands. Additional data can also be gathered, such as acoustic detections, biopsy samples, and photographic identification.

Records of the humpback whale near Trindade Island date back to the first half of the last century until the last few decades (Townsend, 1935; Siciliano, 1997). Our expedition navigated more than $520 \mathrm{~km}$ around Trindade Island and the Archipelago of Martin Vaz over six days. We observed only one single whale, and no male songs were detected during this period. The week before our expedition was in the region, a female with its calf was photographed near the Trindade Island by officials of the Brazilian Navy (the only people who live on the island). Another dedicated expedition visited the Archipelago of Fernando de Noronha and the Rocas Atoll near the peak of the humpback whale breeding season in 2004, but no humpback whales were detected (Baracho et al., 2008; Engel and Marcovaldi, 2007). This evidence strongly suggests that humpback whales are occasional visitors of the oceanic islands of Brazil. Their visits to these remote islands will tend to become more frequent with the observed growth of the population (Ward et al., 2011), but will most likely not be enough to differentiate into another sub-population. Based on our findings, it is plausible that Trindade and Martin Vaz are part of the migratory corridor for whales moving in and out of their breeding habitats along the coast of Brazil. The residence times of the whales that pass through these marginal habitats are most likely very brief, but deserve further evaluation.

The movements of satellite-tagged humpback whales wintering off Brazil showed some individuals navigating through the Vitória Bank, which is part of the Vitória-Trindade seamounts (Zerbini et al., 2011). Here, we demonstrate that these seamounts, specifically the mounts and banks near the Abrolhos Bank (Vitória, Davis, and Jaseur Banks) may serve as breeding habitats for the species. Competitive groups and females with their calves were observed in the shallow tops of the seamounts at the peak of the breeding season. Although no songs were detected in deep waters, the presence and number of singers gradually increased across the seamounts while approaching the Abrolhos Bank. Acoustic stations are a feasible method for detecting the intensity of the breeding activity of humpback whales and should be used in conjunction with visual surveys as a complementary technique.

Although photo-identification data and biopsy samples were collected during the expedition, sample sizes were not sufficient to draw any conclusions about stock identity. The genetic differentiation between these samples has not been tested due the small number of samples from the Vitória-Trindade seamounts. The collection of more samples from these seamounts is necessary to test genetic differentiation and/or increase the opportunity to find matches among these regions.

\subsection{Other cetacean records}

Although we certainly did not sample the whole range of diversity of the cetaceans of the pelagic waters off eastern Brazil, the surroundings of Martin Vaz and the Trindade Islands, and the Vitória-Trindade seamounts, relevant records are presented in this work. Below, we provide a brief discussion of each species observed:

- Antarctic minke whale: this species breeds in Brazilian waters from June to December, but the peak of the breeding season spans from September to November (Williamson, 1975). Thousands of Antarctic minke whales were hunted off the northeastern coast of Brazil and the Antarctic during the last century (Horwood, 1990), but this species was the most frequently sighted during a recent 4-year survey in offshore waters of the former whaling ground off Costinha in the State of Paraíba - from $6^{\circ}$ to $8^{\circ} \mathrm{S}$, and $33^{\circ}$ to $35^{\circ} \mathrm{W}$ (Andriolo et al., 2010b). Significant numbers of Antarctic minke whales are found in waters deeper than $200 \mathrm{~m}$ from $5^{\circ}$ to $12^{\circ}$ $\mathrm{S}$ (Andriolo et al., 2010b). Still, little information exists about the southern and northern limits of the breeding ground of Antarctic minke whales off Brazil. Based on our confirmed sighting (and two additional unidentified but probable records during the expedition), it seems that the waters we surveyed (from $19^{\circ}$ to $21^{\circ} \mathrm{S}$ ) are used by minke whales for breeding, but our data are insufficient to arrive at any conclusion. The southern limits of this species' breeding ground are still not clearly defined. The offshore waters we sampled are most likely used for migratory and breeding whales, including what appeared to be mating activity. To our knowledge, there are no records or descriptions of courtship and mating behavior for the Antarctic minke whale. As judged by the physical contact between the two adults, their unusual swimming positions, and their climbing behavior, we observed instances of mating activity. The behavior of one whale trying to climb the other with its belly has already been cited for the southern-right-whale (Eubalaena australis) while mating (Donnelly, 1967). Finally, our sighting was during the peak of the breeding activity of this species (Best, 1982). 
- Rough-toothed dolphin: Rough-toothed dolphins were observed in the oceanic waters and in association with the Antarctic minke whales. Off the coast of Brazil, this species has been observed in deep oceanic waters and over the continental shelf (Lodi and Hetzel, 1999; Rossi-Santos et al., 2006). This dolphin is commonly found to be associated with the humpback whale in the Abrolhos Bank, where it captures fish associated with the whales, such as the sharksucker (Echeneis naucrates, Wedekin et al., 2004). Moreover, the rough-toothed dolphin is regularly associated with floating debris in the eastern tropical Pacific, where they prey on fish that aggregate around flotsam (Pitman and Stinchcomb, 2002). Although there would be no obvious feeding advantage by associating with Antarctic minke whales, interacting with other cetaceans, divers, or non-living structures is apparently a common behavior of rough-toothed dolphins.

- Bottlenose dolphin: this species is regularly recorded as inhabiting deep oceanic waters and over the continental shelf (Jefferson et al., 2008). The species has also been recorded around oceanic islands off Brazil such as the São Pedro and the São Paulo Archipelago (Moreno et al., 2009) and the Rocas Atoll (Baracho et al., 2008). Bottlenose dolphins have been reported around Trindade Island (Carvalho and Rossi-Santos, 2010), which is evidence that this species is commonly found in the area.

- Fin whale: this species inhabits oceanic waters, but their overall range and distribution is not well known (Jefferson et al., 2008). Only three fin whales were hunted at Costinha $\left(\sim 7^{\circ} \mathrm{S}\right)$ between 1910 and 1954, while 84 specimens were hunted at Cabo Frio (23 S) between 1960 and 1963 (Williamson, 1975). The fin whale is rare along the Brazilian coast, with only a few strandings and sightings reported over the past several decades (Zerbini et al., 1997). Moreover, the species is listed as "Endangered" by the International Union for Conservation of Nature (IUCN, 2012). We are unaware of any recently published sightings of this species in Brazilian waters, which may be due to the lack of observation efforts in the oceanic waters of Brazil and/or the depleted status of this species.

- Killer whale: Sightings and strandings of killer whales in Brazilian waters have mainly been reported in the southern and southeastern regions, where the species has been sighted both in coastal and oceanic waters (Ott and Danilewicz, 1998; Secchi and Vaske Junior, 1998; Lodi and Hetzel, 1998; Siciliano et al., 1999; Cherem et al., 2004). The small number of records along the eastern and northeastern coasts of Brazil, however, is most likely due to a combination of low abundance and the limited search efforts in these regions. Generally, this species is more common at high latitudes (Jefferson et al., 2008). There is one stranding record for the species in the Abrolhos Bank (IBJ, unpublished data), but the species was never sighted in this area during a search effort lasting more than 500 days from 1997 to 2004 during the humpback whale breeding season (RossiSantos et al., 2006). Lodi and Hetzel (1998) reported two sightings for the State of Espírito Santo, both in offshore waters. One of these sightings was reported $240 \mathrm{~km}$ from the Trindade Island. Our observation adds information about the occurrence of killer whales in the eastern waters off Brazil.

Tuna fishery depredation on longlines that operate in the Vitória-Trindade seamounts and the slope of the continental shelf of the Abrolhos Bank caused by killer whales has been reported by fishers from southern Bahia. Fishers popularly refer to killer whales as "chati" and suggest that whales only eat the bodies of fishes such as tuna, leaving the heads with the hooks behind. They also report that sharks are not preyed upon by killer whales. Killer whale groups may follow fishing vessels for a long time (possibly more than one day). Fishers sometimes navigate more than eight hours to operate away from the presence of killer whales. The descriptions by fishers from southern Bahia are similar to those from interactions reported in southern Brazilian waters (Secchi and Vaske Junior, 1998). Furthermore, offshore recreational fishers from Espírito Santo State have reported that killer whales may follow their boats while fishing is ongoing (see Lodi and Hetzel, 1998).

\subsection{Concluding remarks}

The main findings of this work are as follows:

- New observations were made of cetaceans in the poorly studied oceanic waters of Brazil. These observations include the occurrence of the endangered and rare fin whale around the Trindade Island and records of Antarctic minke whales, rough-toothed dolphins, bottlenose dolphins, and killer whales, information that contributes to a better understanding of the biology of these species in Brazilian waters.

- The presence of humpback whales off the Trindade Island and its surroundings is most likely occasional, with few sightings and low density.

- Finally, the relatively large number of humpback whale sightings in the Vitória-Trindade seamounts, especially those closer to the Abrolhos Bank, further indicates that these areas may be important habitats for the species along the Brazilian coast.

Acknowledgments - The information regarding the humpback whales' occurrence in the Vitória-Trindade Chain was part of a doctoral thesis by the first author in Zoology at Universidade Federal do Paraná. We thank the expedition team members: Eduardo Camargo, Enrico Marcovaldi, Bernardo Cerqueira, Djalma, João Mário, and Nico. Joana D'Arc Figueiredo coordinated the photo-identification comparisons of humpback whales. We are thankful for the contributions of Dr. Alexandre Zerbini, which greatly improved the manuscript. Marinha do Brasil and Secretaria da Comissão Interministerial para os Recursos do Mar (SECIRM) provided logistical support. Fundação 
ECOAPLUB provided financial support for the expedition. PETROBRAS is the official sponsor of the Instituto Baleia Jubarte. P. C. Simões-Lopes received a research grant from the Brazilian Research Bureau (Conselho Nacional de Desenvolvimento Científico e Tecnológico CNPq/PQ, proc: 310796/2009-1). A research permit was issued by Instituto Chico Mendes de Conservação da Biodiversidade (ICMBio), number 21489-1.

\section{References}

ANDRIOLO, A., KINAS, P.G., ENGEL, M.H., MARTINS, C.C.A. and RUFINO, A.M., 2010a. Humpback whales within the Brazilian breeding ground: distribution and population size estimate. Endangered Species Research, vol. 11, p. 233-243. http://dx.doi.org/10.3354/esr00282

ANDRIOLO, A., ROCHA, J.M., ZERBINI, A.N., SIMÕESLOPES, P.C., MORENO, I.B., LUCENA, A., DANILEWICZ, D. and BASSOI, M., 2010b. Distribution and relative abundance of large whales in a former whaling ground off eastern South America. Zoologia, vol. 27, no. 5, p. 741-750. http://dx.doi. org/10.1590/S1984-46702010000500011

BARACHO, C.B., CIPOLOTTI, S., MARCOVALDI, E., APOLINÁRIO, M. and SILVA, M.B., 2008. The occurrence of bottlenose dolphins (Tursiops truncatus) in the biological reserve of Atol das Rocas in north-eastern Brazil. Marine Biodiversity Records, vol. 1, p. e75. http://dx.doi.org/10.1017/S1755267207007920

BARACHO-NETO, C.B., SANTOS NETO, E., ROSSI-SANTOS, M.R., WEDEKIN, L.L., NEVES, M.C., LIMA, F. and FARIA, D., 2012. Site fidelity and residence times of humpback whales (Megaptera novaeangliae) on the Brazilian coast. Journal of the Marine Biological Association of the U.K., vol. 92, p. 1783-1791. http://dx.doi.org/10.1017/S0025315411002074

BEST, P.B., 1982. Seasonal abundance, feeding, reprodution, age, and growth in minke whales off Durban. Report of the International Whaling Commission, vol. 32, p. 759-786.

CARVALHO, M.S. and ROSSI-SANTOS, M.R., 2010. Sightings of the bottlenose dolphins (Tursiops truncatus) in the Trindade Island, Brazil, South Atlantic Ocean. Marine Biodiversity Records, vol. 4, p. e15. http://dx.doi.org/10.1017/S1755267211000029

CHEREM, J.J., SIMÕES-LOPES, P.C., ALTHOFF, S. and GRAIPEL, M.E., 2004. Lista dos mamíferos do Estado de Santa Catarina, sul do Brasil. Mastozoologia Neotropical, vol. 11, no. 2, p. 151-184.

CYPRIANO-SOUZA, A.L., FERNÁNDEZ, G.P., LIMA-ROSA, C.A.V., ENGEL, M.H. and BONATTO, S.L., 2010. Microsatellite genetic characterization of the humpback whale (Megaptera novaeangliae) breeding ground off Brazil (Breeding stock A). Journal of Heredity, vol. 101, no. 2, p. 189-200. http://dx.doi. org/10.1093/jhered/esp097

DONNELLY, B.G., 1967. Observations on the mating behavior of the southern right whale Eubalaena australis. South African Journal of Science, vol. 63, no. 5, p. 176-181.

ENGEL, M.H. and MARCOVALDI, E., 2007. Brasil Mar das Baleias. São Paulo: Editora Bambu. 216 p.

HORWOOD, J., 1990. Biology and Exploitation of the Minke Whale. Boca Raton: CRC Press. 238 p.
International Union for Conservation of Nature - IUCN, 2012. IUCN Red List of Threatened Species. version 2012.1. Available from: <www.iucnredlist.org>. Access in: 28 Aug. 2012.

International Whaling Commission - IWC, 1998. Annex G Report of the sub-committee on comprehensive assessment of Southern Hemisphere humpback whales. Report of the IWC, vol. 48, p. 170-182.

International Whaling Commission - IWC, 2006. Report of the Workshop on the Comprehensive Assessment of Southern Hemisphere Humpback Whales. In Proceedings of the 58th Annual Meeting of the Scientific Committee of the International Whaling Commission, 2006. St. Kitts and Nevis: IWC. Working Paper SC/58/Rep 5.

JEFFERSON, T.A., WEBBER, M.A. and PITMAN, R.L., 2008. Marine Mammals of the World: A comprehensive guide to their identification. London: Academic Press. 573 p.

KATONA, S.K. and WHITEHEAD, H., 1981. Identifying humpback whales using their natural markings. Polar Record, vol. 20, p. 439-444. http://dx.doi.org/10.1017/S003224740000365X

KELLOGG, R., 1929. What is known of the migration of some of the whalebone whales. Smithsonian Institution Annual Report, vol. 1928, p. 467-494.

LODI, L., 1994. Ocorrências de baleias-jubarte, Megaptera novaeangliae, no Arquipélago de Fernando de Noronha, incluindo um resumo de registros de capturas no Nordeste do Brasil. Biotemas, vol. 7, p. 116-123.

LODI, L. and HETZEL, B., 1998. Orcinus orca (Cetacea; Delphinidae) em águas costeiras do Estado do Rio de Janeiro. Bioikos, vol. 12, no. 1, p. 46-54.

-, 1999. Rough-toothed dolphin, Steno bredanensis, feeding behaviors in Ilha Grande Bay, Brazil. Biociências, vol. 7, no. 1, p. 29-42.

MARTINS, C.C.A., MORETE, M.E., ENGEL, M.H., FREITAS, A.C., SECCHI, E.R. and KINAS, P.G., 2001. Aspects of habitat use patterns of humpback whales in the Abrolhos Bank, Brazil, breeding ground. Memoirs of the Queensland Museum, vol. 47, p. $563-570$

MORENO I.B., OTT, P.H., TAVARES, M., OLIVEIRA, L.R., DANILEWICZ, D., SICILIANO, S. and BONNATO, S., 2009. Os Cetáceos com ênfase no golfinho nariz-de-garrafa, Tursiops truncatus (Montagu, 1821). In VIANA, D.L., HAZIN, F.H.V. and SOUZA, MAC. (Eds.). O Arquipélago de São Pedro e São Paulo: 10 anos de Estação Científica. Brasília: SECIRM. 348 p.

OTT, P.H. and DANILEWICZ, D., 1998. Presence of franciscana dolphins (Pontoporia blainvillei) in the stomach of a killer whale (Orcinus orca) stranded in southern Brazil. Mammalia, vol. 62, no. 4 , p. 605-609.

PAYNE, R.S. and MCVAY, S., 1971. Songs of humpback whales. Science, vol. 173, p. 585-597. PMid:17833100. http://dx.doi. org/10.1126/science.173.3997.585

PITMAN, R.L. and STINCHCOMB, C., 2002. Rough-toothed dolphins (Steno bredanensis) as predators of Mahimahi (Coryphaena hippurus). Pacific Science, vol. 56, no. 4, p. 447-450. http://dx.doi. org/10.1353/psc.2002.0043

ROSSI-SANTOS, M.R., WEDEKIN, L.L. and SOUSA-LIMA, R.S., 2006. Distribution and habitat use of small cetaceans in the Abrolhos Bank, Eastern Brazil. Latin American Journal 
of Aquatic Mammals, vol. 5, no. 1, p. 23-28. http://dx.doi. org/10.5597/lajam00088

SECCHI, E. and VASKE JUNIOR, T., 1998. Killer whale (Orcinus orca) sightings and depredation on tuna and swordfish longline catches in southern Brazil. Aquatic Mammals, vol. 24, no. 2, p. 117-122.

SICILIANO, S., 1997. Características da população de baleiasjubarte (Megaptera novaeangliae) na costa brasileira, com especial referência aos Bancos de Abrolhos. Seropédica: Universidade Federal Rural do Rio de Janeiro. 113 p. Dissertação de Mestrado

SICILIANO, S., BRITO JUNIOR, J.L. and AZEVEDO, A.F., 1999. Seasonal occurrence of killer whales (Orcinus orca) in waters of Rio de Janeiro, Brazil. Zeitschrift für Säugetierkunde, vol. 64 , p. 251-255.

SILVA, M.B. and GODOY, T., 2010. Avistagens oceânicas de cetáceos entre Natal e a Reserva Biológica do Atol das Rocas / RN. In Abstracts of the XIV Reunião de Trabalho (RT) de Especialistas em Mamíferos Aquáticos da América do Sul, 2010. Florianópolis: SOLAMAC.

TOWNSEND, C.H., 1935. The distribution of certain whales as shown by logbook of American whaleships. Zoologica, vol. 19, no. 1, p. 1-50.

TYACK, P. and WHITEHEAD, H., 1983. Male competition in large groups of wintering humpback whales. Behaviour, vol. 83, no. 1-2, p. 132-154. http://dx.doi.org/10.1163/156853982X00067

WARD, E., ZERBINI, A.N., KINAS, P.G., ENGEL, M.H. and ANDRIOLO, A., 2011. Estimates of population growth rates of humpback whales (Megaptera novaeangliae) in the wintering grounds off the coast of Brazil (Breeding Stock A). Journal of Cetacean Research and Management, Special Issue 3, p. 145-149.

WEDEKIN, L.L., FREITAS, A.C., ENGEL, M.H. and SAZIMA, I., 2004. Rough-toothed-dolphin (Steno bredanensis) catch diskfishes while interacting with humpback whales (Megaptera novaeangliae) off Abrolhos Bank breeding ground, Southwest Atlantic. Aquatic Mammals, vol. 30, no. 2, p. 327-329. http:// dx.doi.org/10.1578/AM.30.2.2004.327

WEDEKIN, L.L., NEVES, M., BARACHO, C., ROSSI-SANTOS, M.R., MARCONDES, M., ENGEL, M. and SIMÕES-LOPES, P.C., 2010. Site fidelity and movements of humpback whales (Megaptera novaeangliae) in the Brazilian breeding ground, southwestern Atlantic. Marine Mammal Science, vol. 26, no. 4, p. 787-802. http://dx.doi.org/10.1111/j.1748-7692.2010.00387.x

WILLIAMSON, G.R., 1975. Minke whales off Brazil. Scientific Report of the Whales Research Institute, vol. 27, p. 37-59.

ZERBINI, A.N., SECCHI, E.R., SICILIANO, S. and SIMÕESLOPES, P.C., 1997. A review of the occurrence and distribution of whales of the genus Balaenoptera along the Brazilian coast. Report of the International Whaling Commission, vol. 47, p. 407-417.

ZERBINI, A.N., ANDRIOLO, A., HEIDE-JORGENSEN, M.P., MOREIRA, S., PIZZORNO, J.L., MAIA, Y.G., VANBLARICON, G.R. and DEMASTER, D.P., 2011. Migration and summer destinations of humpback whales (Megaptera novaeangliae) in the western South Atlantic Ocean. Journal of Cetacean Research and Management, Special Issue 3, p. 113-118. 